\title{
Pengaruh Earning Per Share dan Economic Value Added terhadap Return Saham pada Perusahaan yang Terdaftar di Jakarta Islamic Index
}

\author{
Choirul Imroatin, Purweni Widhianningrum \\ Pendidikan Akuntansi, FKIP Universitas PGRI Madiun \\ Jl. Setiabudi No. 85 Madiun, Jawa Timur 63118 \\ weni.widhi@gmail.com
}

\begin{abstract}
$A B S T R A C T$
This study aimed to analyze the influence Earning Per Share and Economic Value Added on stock returns. This study is a quantitative research. The population in this study is a company registered in the group of Jakarta Islamic Index period in 2011, 2012, 2013, and 2014. The sampling technique used purposive sampling, so the final number of samples acquired 11 companies. The data analysis used is multiple linear regression. The results proved that Earning Per Share and Economic Value Added have a significant effect on stock returns in Jakarta Islamic Index period in 2011, 2012, 2013, and 2014.
\end{abstract}

Keywords: Earning Per Share, Economic Value Added, Return, Jakarta Islamic Index.

\section{PENDAHULUAN}

Indonesia dikenal sebagai negara muslim terbesar di dunia dan juga pasar yang sangat besar untuk pengembangan industri keuangan Syariah. Investasi Syariah di pasar modal mempunyai peranan yang cukup penting untuk dapat meningkatkan pangsa pasar industri keuangan Syariah di Indonesia. Meskipun perkembangannya relatif baru dibandingkan dengan perbankan Syariah maupun asuransi Syariah tetapi seiring dengan pertumbuhan yang signifikan di industri pasar modal Indonesia, maka diharapkan investasi Syariah di pasar modal Indonesia akan mengalami pertumbuhan yang pesat. Selama ini, investasi Syariah di pasar modal Indonesia identik dengan Jakarta Islamic Index (JII) yang hanya terdiri dari 30 saham Syariah yang tercatat di Bursa Efek Indonesia (BEI). Padahal Efek Syariah yang terdapat di pasar modal Indonesia bukan hanya 30 saham Syariah yang menjadi konstituen JII saja tetapi terdiri dari berbagai macam jenis Efek selain saham Syariah yaitu Sukuk, dan reksadana Syariah (www.idx.co.id).

Saham syariah di Jakarta Islamic Index dirasa sangat penting pengaruhnya bagi Indonesia. Saham-saham yang tergabung di dalamnya mampu meningkatkan perekonomian Indonesia. Artinya, Indonesia berpotensi besar menjadi pusat perkembangan produk investasi berbasis syariah baik di tingkat global maupun tingkat regional. Data sampai akhir tahun 2015, pertumbuhan pangsa pasar saham syariah lebih dominan dibandingkan dengan non syariah. Jumlah saham yang tercatat sebanyak 318 saham atau $61 \%$ dari total kapitalisasi pasar saham Indonesia (Soekarno, 2016).

Istilah high risk, high return dalam pasar modal, mengindikasikan bahwa saham memungkinkan investor memperoleh keuntungan dalam jumlah besar dalam waktu singkat, namun seiring dengan berfluktuasinya harga saham, maka investor dapat juga mengalami kerugian besar dalam waktu yang singkat (Darmadji

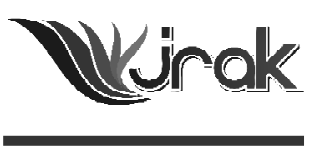

Jurnal Reviu Akuntansi dan Keuangan

ISSN: 2088-0685

Vol.5 No. 1, April 2015 Pp 705-710 
Pengaruh Earning Per Share...

706 dan Fakhruddin, 2012: 10). Oleh karenanya, analisis fundamental digunakan untuk mempraktikkan harga saham di masa yang akan datang dengan mengestimasi nilai faktor-faktor fundamental yang mempengaruhi harga saham di masa yang akan datang (Martalena dan Malinda, 2011: 47). Dan faktor yang dapat mempengaruhi harga saham adalah kinerja perusahaan (Halim, 2015: 4).

Penelitian terdahulu membuktikan bahwa kinerja perusahaan yang diproksikan oleh Earning Per Share (Ganto, et. al, 2008; Hermawan, 2012, Nuryana, 2013; Margaretha dan Isni, 2007 dan Janitra dan Kesuma, 2015) dan Economic Value Added (Alexander dan Destriana, 2013; Fibriyantini dan Purwohandoko, 2013; Dwimulyani dan Djamhuri, 2014; dan Himawan dan Sukardi, 2009) berpengaruh signifikan terhadap return saham. Menurut Margaretha dan Isni (2007: 73-74), Earning Per Share yang tinggi mencerminkan tingginya tingkat laba per lembar saham bagi para pemegang saham dan meningkatkan kepercayaan investor bahwa perusahaan akan memberikan pengembalian yang cukup baik. Tingkat pengembalian yang baik akan mendorong pihak investor untuk melakukan investasi yang lebih besar, sehingga harga saham perusahaan pun meningkat. Syamsuddin (2011: 66) berargumen bahwa ketertarikan manajemen perusahaan, pemegang saham biasa dan calon pemegang saham terhadap Earning Per Share adalah rasio tersebut merupakan salah satu indikator keberhasilan suatu perusahaan yang mampu menggambarkan jumlah rupiah yang diperoleh untuk setiap lembar saham biasa.

Sedangkan Economic Value Added merupakan nilai tambah ekonomis yang diciptakan perusahaan dari kegiatan atau strateginya selama periode tertentu dan merupakan salah satu cara untuk menilai kinerja keuangan (Dwimulyani dan Djamhuri, 2014: 113). Economic Value Added membantu perusahaan untuk menentukan apakah uang yang didapatkannya lebih besar daripada uang yang digunakan untuk mendapatkan uang tersebut. Dalam jangka panjang, hanya perusahaan-perusahaan yang menghasilkan modal atau kekayaan yang dapat bertahan (Hansen dan Mowen, 2012: 585).

Berdasarkan penelitian terdahulu, maka peneliti ingin meneliti lebih lanjut dengan tujuan untuk mengetahui pengaruh Earning Per Share terhadap return saham dan Economic Value Added terhadap return saham perusahaan. Perbedaan penelitian ini dengan penelitian terdahulu adalah bahwa penelitian ini dilakukan pada perusahaan yang terdaftar dalam kelompok Jakarta Islamic Index periode tahun 2011-2014.

\section{METODE PENELITIAN}

\section{Jenis Penelitian}

Penelitian ini tergolong dalam penelitian kuantitatif dengan jumlah populasi sebanyak 46 perusahaan yang terdaftar di Jakarta Islamic Index (JII) selama periode tahun 2011, 2012, 2013, dan 2014. Berdasarkan teknik purposive sampling, maka diperoleh jumlah sampel sebanyak 11 perusahaan. Teknik analisis data yang digunakan dalam penelitian ini terdiri dari analisis statistik deskriptif dan analisis regresi linier berganda. Untuk memperoleh model regresi dengan estimasi yang tidak bias dan dapat dipercaya, maka dilakukan uji asumsi klasik (normalitas, multikolinieritas, autokorelasi, dan heteroskedastisitas) pada model regresi (Priyatno, 2014: 89). Alat analisis yang digunakan adalah Statistic Product and Service Solution (SPSS) versi 22.

Jenis data dalam penelitian ini bersumber dari data sekunder berupa laporan keuangan dan laporan tahunan perusahaan yang terdaftar di Jakarta Islamic Index (JII). Data tersebut diperoleh melalui www.idx.co.id. Metode analisis data dalam penelitian ini menggunakan Regresi Linier Berganda. Pengukuran variabel penelitian dijelaskan dalam tabel sebagai berikut: 


\begin{tabular}{|c|c|c|}
\hline Variabel Terukur & Proksi & Sumber \\
\hline $\begin{array}{l}\text { Earning Per Share } \\
\left(\mathrm{X}_{1}\right)\end{array}$ & $\mathrm{EPS}=\frac{E A T}{J_{s b}} \times 100 \%$ & $\begin{array}{l}\text { Fahmi } \\
(2013: 138)\end{array}$ \\
\hline $\begin{array}{l}\text { Economic } \\
\text { Added }\left(\mathrm{X}_{2}\right)\end{array}$ & $\begin{array}{l}\text { EVA }= \\
\text { NOPAT - (WACC x Invested Capital) }\end{array}$ & $\begin{array}{l}\text { Dwimulyani } \\
\text { dan Djamhuri } \\
(2014: 115)\end{array}$ \\
\hline Return Saham (Y) & $\mathrm{Rt}=\frac{\left(P_{t}-P_{t-1}\right)+D_{t} \mathrm{x}}{P_{t-1}} 100 \%$ & $\begin{array}{l}\text { Hartono } \\
(2013: 237)\end{array}$ \\
\hline
\end{tabular}

Sumber: data diolah, 2016

\section{HASIL DAN PEMBAHASAN}

\section{Statistik Deskriptif}

\begin{tabular}{llllll}
\hline & N & Minimum & Maximum & Mean & Std. Deviation \\
\hline $\begin{array}{l}\text { Earning Per } \\
\text { Share }\end{array}$ & 44 & 2157,23 & 166430,16 & 45733,4664 & 51308,86619 \\
$\begin{array}{l}\text { Economic } \\
\text { Value Added }\end{array}$ & 44 & - & & & \\
$\begin{array}{l}\text { Return } \\
\text { Saham }\end{array}$ & 44 & $-37,85$ & 173,80 & 22,6183 & 38,54263 \\
& & & 1040391126583 & 256320924316 & 347034240517 \\
\end{tabular}

Tabel 2

Hasil Statistik

Deskriptif

Sumber: data diolah, 2016

Hasil statistik deskriptif menunjukkan bahwa nilai terendah Earning Per Share diperoleh sebesar 2157,23, dengan nilai tertinggi sebesar 166430,16, sedangkan nilai rata-rata sebesar 45733,4664. Nilai terendah Economic ValueAdded diperoleh sebesar -794106531578,00, dengan nilai tertinggi sebesar 1040391126583, sedangkan nilai rata-rata sebesar 256320924316. Nilai terendah return saham diperoleh sebesar $-37,85$, dengan nilai tertinggi sebesar 173,80 , sedangkan nilai rata-rata sebesar 22,6183 .

\section{Uji Asumsi Klasik}

\begin{tabular}{lll}
\hline Model & Tolerance & VIF \\
\hline Constant & & \\
$\mathrm{X}_{1}$ & 0,736 & 1,358 \\
$\mathrm{X}_{2}$ & 0,736 & 1,358 \\
Kolmogorov Smirnov & $\mathrm{N}=44$ & \\
& Asymp. Sig. (2-tailed) $=0,200$ & \\
Durbin-Watson & 2,201 & \\
Sumber: data diolah, 2016 & &
\end{tabular}

Tabel 3

Hasil Uji Asumsi Klasik

Dari tabel di atas menunjukkan bahwa nilai signifikansi Asymp. Sig Kolmogorov Smirnov sebesar 0,200 > 0,05, sehingga dapat disimpulkan bahwa data berdistribusi normal atau memenuhi asumsi klasik normalitas. Nilai VIF sebesar 1,358 $<10$ dan nilai tolerance sebesar 0,736 > 0,1 menunjukkan bahwa model regresi tidak terjadi multikolinearitas antar variabel independen. Nilai Durbin-Watson sebesar 2,201 pada taraf signifikansi 0,05. Nilai ini menunjukkan bahwa $1,6120<$ $2,201<2,388$, sehingga dapat disimpulkan bebas autokorelasi. Uji heteroskedastisitas dilakukan dengan pengamatan pada grafik pada scater plot sebagai berikut: 


\section{Pengaruh Earning Per Share...}

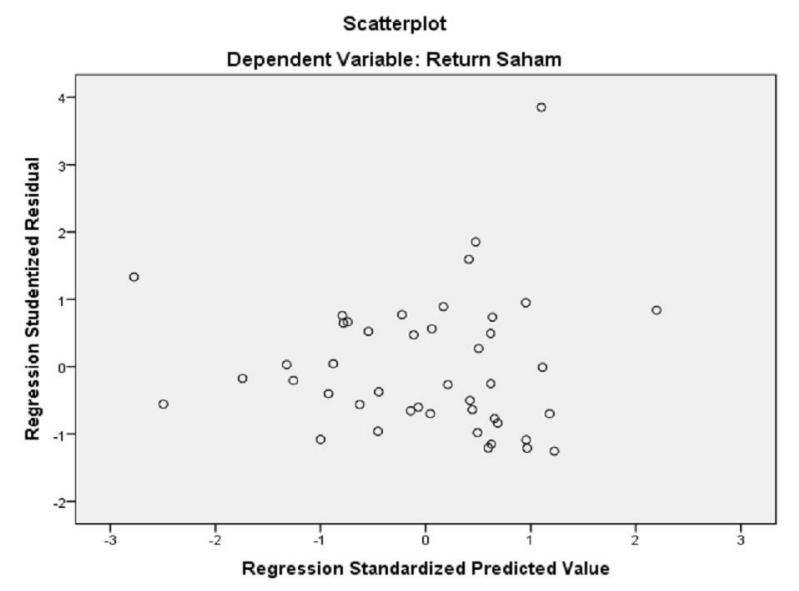

Dari gambar grafik scater plot di atas memperlihatkan bahwa titik-titik pada grafik menunjukkan titik-titik menyebar secara acak serta tersebar baik di atas dan di bawah angka 0 pada sumbu Y, maka disimpulkan bahwa tidak terjadi heteroskedastisitas.

\section{Uji Hipotesis}

\begin{tabular}{lll}
\hline \multirow{2}{*}{ Model } & \multicolumn{2}{c}{ Unstandardized Coefficients } \\
\cline { 2 - 2 } & $\mathbf{B}$ & sig \\
\hline (Constant) & 23,007 &, 003 \\
Earning Per Share &, 000 &, 014 \\
Economic Value Added & $5,442 \mathrm{E}-11$ &, 004 \\
F hitung & 5,262 & \\
sig &, 009 & \\
\hline Sumber: data diolah, 2016 &
\end{tabular}

Berdasarkan hasil uji regresi yang telah dilakukan, diketahui bahwa nilai signifikansi Earning Per Share sebesar 0,004 yang kurang dari tingkat signifikansi 0,05. Hal ini membuktikan bahwa $\mathrm{H}_{1}$ yang menyatakan bahwa Earnings Per Share berpengaruh signifikan terhadap return saham, diterima. Hasil penelitian ini mendukung penelitian terdahulu yang telah dilakukan oleh Ganto, et al. (2008), Hermawan (2012), Margaretha dan Isni (2007), dan Janitra dan Kesuma (2015). Menurut Ganto et al. (2008: 89) investor memiliki kepercayaan bahwa return suatu saham akan tergantung pada kemampuan perusahaan dalam menghasilkan earning untuk tiap lembar sahamnya. Sehingga semakin tinggi tingkat Earning Per Share pada suatu perusahaan akan berdampak pada semakin tinggi return saham yang diterima oleh investor (Hermawan, 2012: 5).

Selain itu, saham perusahaan yang terdaftar dalam kelompok Jakarta $I_{S^{-}}$ lamic Index merupakan saham syariah yang mempunyai batasan hutang berbasis bunga. Adanya batasan dalam perolehan hutang dan pendapatan berbasis bunga menunjukkan tingginya tingkat pendanaan perusahaan dalam kelompok Jakarta Islamic Index yang berasal dari modal pemilik dan kondisi perusahaan tidak begitu dipengaruhi oleh kenaikan tingkat bunga pinjaman yang akan meningkatkan beban bunga kredit dan menurunkan laba bersih perusahaan. Selain itu, perusahaan di Jakarta Islamic Index memiliki struktur modal yang sehat karena tidak terbebani bunga hutang berlebihan. Karena, modal perusahaan banyak yang berasal dari pemilik perusahaan daripada hutang. Dengan demikian, Earning Per Share pada perusahaan kelompok Jakarta Islamic Index cenderung stabil dan mengalami kenaikan yang berdampak pada meningkatnya return saham.

Berdasarkan hasil uji hipotesis yang telah dilakukan, Economic ValueAdded memiliki nilai probability signifikansi sebesar 0,004, nilai ini lebih kecil dari tingkat signifikansi sebesar 0,05. Hasil ini membuktikan bahwa $\mathrm{H}_{2}$ yang menyatakan 
bahwa Economic Value Added berpengaruh signifikan terhadap return saham, diterima. Penelitian ini mendukung penelitian yang dilakukan oleh Alexander dan Destriana (2013), Fibriyantini dan Purwohandoko (2013), Setianan dan Adwitya (2011), dan Dwimulyani dan Djamhuri (2014) Menurut Setianan dan Adwitya (2011: 63), perusahaan yang mampu menghasilkan tingkat pengembalian yang lebih besar dari biaya modalnya maka perusahaan dinilai berhasil menciptakan Economic Value Added. Oleh karenanya, apabila Economic Value Added meningkat maka dapat dikatakan bahwa laba yang diperoleh perusahaan dapat menutupi biaya modal yang dikeluarkan oleh perusahaan sehingga investor akan menerima pengembalian dari selisih tersebut (Alexander dan Destriana, 2013: 130).

Pengaruh Economic Value Added terhadap return saham pada perusahaan yang terdaftar dalam kelompok Jakarta Islamic Index dikarenakan sebagian besar perusahaan tersebut melakukan kegiatan investasi pada proyek-proyek yang menguntungkan. Artinya, perusahaan mampu memberdayakan modal dengan baik, sehingga tercipta nilai tambah bagi pemegang saham. Economic Value Added yang meningkat menunjukkan bahwa laba yang diperoleh perusahaan dapat menutup biaya modal yang dikeluarkan perusahaan dalam melakukan kegiatan investasi pada proyek-proyek yang menguntungkan. Laba perusahaan yang diperoleh dari kegiatan investasi tersebut akan berpengaruh terhadap return saham yang dibagikan perusahaan kepada investor.

\section{KESIMPULAN}

Berdasarkan hasil dari penelitian ini dapat disimpulan bahwa earning per share dan economic value added berpengaruh signifikan terhadap return saham pada perusahaan yang terdaftar di Jakarta Islamic Index. Earning per share yang tinggi mencerminkan tingkat laba per lembar saham yang tinggi bagi investor. Sehingga, investor percaya bahwa perusahaan akan memberikan tingkat pengembalian atau return yang baik. Saham perusahaan yang terdaftar dalam kelompok Jakarta Islamic Index merupakan saham syariah yang mempunyai batasan hutang berbasis bunga. Hal ini mengakibatkan earning per share pada perusahaan kelompok Jakarta Islamic Index cenderung stabil dan mengalami kenaikan, sehingga berdampak pada meningkatnya return saham. Sedangkan economic value added yang meningkat atau bernilai positif berarti perusahaan memperoleh keuntungan lebih besar dari biaya modal yang dikeluarkan. Sehingga, tingkat pengembalian atau return juga akan mengalami peningkatan. Perusahaan-perusahaan dalam kelompok Jakarta Islamic Index banyak yang melakukan investasi dalam bentuk saham, tanah, bangunan, properti, persewaan, dan juga investasi pada entitas asosiasi. Investasi pada proyek tersebut akan berdampak pada peningkatan keuntungan perusahaan yang berdampak pada meningkatnya return saham yang dibagikan kepada investor.

Adapun saran yang dapat diberikan untuk penelitian selanjutnya adalah diharapkan dapat memperluas sampel yang digunakan, tidak terbatas pada perusahaan yang terdaftar di Jakarta Islamic Index tetapi dapat menggunakan sampel perusahaan yang terdaftar di Indeks Saham Syariah Indonesia (Indonesia Sharia Stock Index). Penelitian selanjutnya dapat menggunakan ukuran kinerja keuangan yang lain seperti, current ratio, return on investment, residual income, profit margin, return on assets, dan debt to total assets ratio.

\section{DAFTAR PUSTAKA}

Alexander, Nico dan Destriana, Nicken. 2013. Pengaruh Kinerja Keuangan Terhadap Return Saham. Jurnal Bisnis dan Akuntansi, Vol. 15, No. 2, p.123132 . 
Pengaruh Earning

Per Share...

710
Darmadji, Tjiptono dan Hendy M. Fakhrudin. 2012. Pasar Modal di Indonesia Pendekatan Tanya Jawab. Jakarta: Salemba Empat.

Dwimulyani, Susi dan Djamhuri. 2014. Pengaruh Economic Value Added, Market Value Added dan Good Corporate Governance Terhadap Return Saham pada Perusahaan Publik yang Mendapat Pemeringkatan dari The Indonesian Institute for Corporate Governance. Indonesia Accounting Research Journal, Vol. 2, No. 2, p. 108-121.

Fahmi, Irham. 2015. Pengantar Manajemen Keuangan Teori dan Soal Jawab. Bandung: Alfabeta.

Fibriyantini, Ria Rezha dan Purwohandoko. 2013. Analisis Pengaruh Economic Value Added, Residual Income, Earnings dan Arus Kas Operasi Terhadap Return Saham. Jurnal Ilmu Manajemen, Vol. 1, No. 4, p. 1186-1198.

Ganto, Jullimursyida, Muamar Khadafi, Wahyudin Albra dan Gazali Syamni. 2008. Pengaruh Kinerja Keuangan Perusahaan Manufaktur Terhadap Return Saham di Bursa Efek Indonesia. Media Riset Akuntansi, Auditing dan Informasi, Vol. 8, No. 1, p. 85-96.

Halim, Abdul. 2015. Analisis Investasi dan Aplikasinya. Jakarta: Salemba Empat.

Hansen, Don R., dan Maryanne M. Mowen. 2012. Akuntansi Manajerial. Jakarta: Salemba Empat.

Hariani, Lilik Sri. 2010. Analisis Pengaruh Economic Value Added(EVA) dan Rasio Keuangan Terhadap Return Saham Syariah. Jurnal Ekonomi Modernisasi Fakultas Ekonomi-Universitas Kanjuruhan Malang, Vol. 6, No. 1, p.1-21.

Hartono, Jogiyanto. 2013. Teori Portofolio dan Analisis Investasi. Yogyakarta: BPFE.

Hermawan, Dedi Aji. 2012. Pengaruh Debt to Equity Ratio, Earning Per Share dan Net Profit Margin Terhadap Return Saham. Manajement Analysis Journal, Vol. 1, No. 5, p.1-7.

Hery. 2015. Analisis Kinerja Manajemen. Jakarta: Grasindo.

Himawan, F. Agung dan Sukardi. 2009. Pengaruh Economic Value Added, Market Value Added dan Operating Income Terhadap Return Saham pada Industri Sektor Mining di Bursa Efek di Indonesia Periode 2003-2007. Jurnal Esensi, Vol. 12, No. 3, p. 53-83.

Janitra, Putu Vito Veda dan I Ketut Wijaya Kesuma. 2015. Pengaruh EPS, ROI dan EVA Terhadap Return Saham Perusahaan Otomotif di BEI. E-Jurnal Manajemen Unud, Vol. 4, No. 7, p. 1831-1844.

Margaretha, Farah dan Isni. 2007. Pengaruh Indikator Keuangan Terhadap Harga Saham. Jurnal Ilmiah Manajemen Bisnis, Vol. 7, No. 1, p. 59-78.

Martalena dan Malinda. 2011. Pengantar Pasar Modal. Yogyakarta: ANDI.

Nuryana, Ida. 2013. Pegaruh Rasio Keuangan Terhadap Return Saham Perusahaan LQ45 di Bursa Efek Jakarta. Jurnal Akuntansi Aktual, Vol. 2, No. 2, p. 57-66.

Priyatno, Dwi. 2014. SPSS Pengolah Data Terpraktis. Yogyakarta: Andi.

PT Bursa Efek Indonesia. IDX Statistics 2011-2014. http://www.idx.co.id/id-id/ beranda/produkdanlayanan/pasarsyariah.aspx (diakses pada 11 Mei 2016).

Setianan, Andreas Ronald dan Astika Rizky Adwitya. 2011. Analisis Pengaruh Pertumbuhan Aset dan Eva Terhadap Return Saham. Jurnal Bisnis dan Ekonomi, Vol. 2, No. 1, p. 54-67.

Soekarno. 2016. Press Release:Tingkatkan Literasi Keuangan Masyarakat Melalui Festival Pasar Modal Syariah 2016. www.idx.co.id (diakses pada 10 Mei 2016).

Syamsuddin, Lukman. 2011. Manajemen Keuangan Perusahaan: Konsep Aplikasi dalam Perencanaan, Pengawasan, dan Pengambilan Keputusan. Jakarta: Rajawali Pers. 